\title{
Rural Development Projects, Schooling and Territorial Transformations: A Case Study in Indigenous Communities of Andean Argentina
}

\author{
Jorge Luis Cladera ${ }^{1 *}$ \\ ${ }^{1}$ Universidad de Buenos Aires. Facultad de Filosofia y Letras, Instituto Interdisciplinario de Tilcara, ARGENTINA
}

*Corresponding Author: chorchcladera@gmail.com

Citation: Cladera, J. L. (2020). Rural Development Projects, Schooling and Territorial Transformations: A Case Study in Indigenous Communities of Andean Argentina, Journal of Cultural Analysis and Social Change, 5(1), 05. https://doi.org/10.20897/jcasc/8297

Published Online: May 23, 2020

\begin{abstract}
This article analyzes, in four Andean indigenous communities in northwestern Argentina, the dynamics of transformation of pastoral territoriality that are occurring in recent times. A conceptual device developed by another author - the distinction between two-dimensional and zero-dimensional forms of tenure (Ingold 1987) - is used to identify the demarcation criteria underlying different native terms to designate the domestic group places. The territorial transformations that are taking place today are identified fundamentally in two family investment priorities: in building new houses, or in installing fences for the enclosure of plots. Both investment targets point to the growing economic role of rural schools as a factor that drives local economical circulations. For domestic groups with schooled children, the priority becomes to get employment at school. For domestic groups in the fission stage, the priority is to intensify local agricultural and livestock production in order to take profit of the money circulation circuits and input demands of local schools. In both cases, territorial dynamics tend to focus livestock mobility in more circumscribed and less strenuous transfer ranges, and these dynamics are expressed through modifications in the native categories used to name spaces and places.
\end{abstract}

Keywords: territorial transformations, schooling, pastoralism, domestic groups

\section{INTRODUCTION}

Pastoral societies have been emblematic cases for the study of the articulation between the territoriality of modern States and that of other livelihoods (Barth, 1976, Scott, 1987; 1998) that challenge the capacity of States to establish legible criteria for the modernization of their populations (Scott, 1998): although in all cases they do so from a disadvantageous subaltern condition, which is unstable in the long term. According to this, Andean pastoral societies have been, and continue to be, analyzed as societies in a severe and irremediable process of retreat or even disappearance, due to the expansion of capitalist logics and the hegemonic interventions of modern national States (Medinaceli, 2005). Consequently, some rapid territorial transformations that are taking place nowadays in traditionally pastoral Andean communities, have been analyzed in terms as alarming as 'disaster' (Jacobsen, 2011) or 'catastrophe' (Parker-Gibson, 2015), although not all scholars necessarily agree with this alarmist position (see for instance Kerssen, 2015; Walsh-Dilley, 2016; Winkel et. al., 2015).

In the case of Argentina, in recent years there has been a revival of studies on the Andean pastoral territorialities, both in terms of their continuities and their transformations (Benedetti \& Tomasi, 2014). Some studies have been forced to address the rapid processes of change provoked by mining investments (Abeledo, 2018; Lencina, Peralta \& Sosa Gómez, 2018; Puente \& Argento, 2015; Schiaffini, 2014), and, to a lesser extent, also by rural development 
actions promoted by the State (Cowan Ros, 2007; 2013; Quiroga Mendiola, 2013). Statistical measurement tools manifest firm but inconclusive trends regarding the vitality of pastoral communities. On the one hand, censuses show an intense concentration of the population in departmental capital towns, and a parallel demographic stagnation or decrease in rural areas (Longhi \& Krapovickas, 2018). Likewise, the monetary incomes of rural domestic units coincide with the low importance of agricultural and livestock products, since they depend much more on salary or State incomes (Paz et. al., 2012; Quiroga Mendiola \& Ramisch, 2013). However, some authors suggest that the recent shrinking of labour force markets in Argentina, would have stimulated a reinforcement of rural domestic production in different livestock-herding communities (Paz, 2006), including Andean ones (Hocsman 2011). Some quantifiable information seems to be in line with this viewpoint, such as the increase in the number of camelid livestock in the Argentinian altiplano in recent years (Echenique et al, 2015).

Consequently, the information seems to be contradictory, suggesting in some aspects the decline and in other aspects the vitality of pastoral livelihoods in Argentinean Andes. The impact produced by certain contemporary transformations - specially, mining investments - is of such an overwhelming scale, that it promotes an approach to its effects through a simplified dichotomous model: either pastoral societies become something else, or they perish. This model, although effective in alerting to the impacts that global changes produce in traditional societies, threatens nevertheless to give entity to the naïve classical anthropology perspective of the folk society, whose cultural ontology, focused on an ethos of equilibrium and stasis, would be in a passive situation of cultural erosion provoked by the interference of external factors. This is of course far from being what actually happens. Andean pastoral communities are active agents of the territorial transformations that are taking place, and they activate this agency through a creative use both of the modernization devices offered by the State and of the elements available in their own cultural frameworks for the interpretation and interaction with the territories they inhabit: that is, through a creative manipulation of their own traditional ontologies. My hypothesis is that these societies make active decisions to reconfigure their own territoriality by taking advantage of certain modernization - that is, hegemonic - devices when they are useful, without giving up the specificity of their own pastoral - that is, subaltern - livelihoods. This creative manipulation of hegemonic devices configures territorialities in ways that become confusing when the information is analyzed in dichotomous terms of prevalence or decay of traditional livelihoods. To contrast this hypothesis, I will study in this opportunity the relationship between pastoral territoriality and elementary schools.

In order to apprehend certain non-hegemonic senses of space and place, I have already suggested in another work (Cladera, 2013), what I consider a fruitful set of models of tenure that Tim Ingold (1987) has designed for understanding a completely different kind of social reality. Ingold proposes to rethink the sense of territoriality as a communicational interaction between different social groups for the mutual awareness of the resources that are being used, in order to avoid overexploitation. If the establishment of spatial rights is no longer an exercise of monopolization, then the circumscription of areas of exclusive right by certain collective or individual social subjects - a modality that the author calls two-dimensional tenure - does not necessarily constitute the only possible way to demarcate spatial rights. Another possible modality is the one he calls zero-dimensional tenure. This criterion is established on the recognition of a certain spatial marker - say, a geographical feature, a site, a house, a pond - as the reference point from which the right of a given social subject emanates. The surrounding country cannot be delimited and does not exclude other social agents - whether they be human, animal or spiritual, because what belongs to someone is not an area but the place. Throughout this article, I will try to illustrate how these two different conceptions of tenure give meaning to the various native categories employed for referring to places, as well as the current directions into which these senses are intentionally being transformed.

\section{METHODOLOGY}

The source of information I am using in this article consists of my ethnographic fieldnotes taken between 2007 and 2012 as part of my participation in a Rural Extension Team. Complementarily, I will also use data from a survey conducted during a shorter period - from October 2009 to October 2010 - within that technical fieldwork experience, as part of the formulation requirements established by a project funding programme.

The Rural Extension Team combined the activities of professionals from two national agencies - the National Institute of Agricultural Technology (INTA) and the Programa Social Agropecuario (PSA) - and three different disciplines - agronomists, anthropologists and master builders - with the aim of improving the quality of life of the indigenous communities of a region called the Zenta mountains, or "Sierras del Zenta". Indigenous communities there have been historically submitted to a social and economical exploitation system widespread in HispanicAmerican peasant societies: the hacienda model (Assadourian, 1982; Mörner, 1975). These communities were confined to large estates of colonial origin: Finca Santiago (125,000 hectares) in the current province of Salta; and Finca Rodero y Negra Muerta (164,500 hectares) in what is now the province of Jujuy. For most of the 20th century, indigenous communities were forced to work the sugar cane harvest in the tropical lowland sugar mills of 
Salta and Jujuy to afford the leases for their homelands (Rutledge, 1987; Weinberg, 2004). Since the 1994 constitutional reform recognizing the pre-existence of indigenous peoples in Argentina, the Zenta communities have made significant progress in asserting their rights to their own lands, obtaining in several cases - though not all - their own community property titles. The official recognition of community territories was seen by both the communities and our Rural Extension Team, as an opportunity to improve traditional rural livelihoods.

The surveys were implemented to fulfill the requirements established by a financing program called PROINDER (Project for the Development of Agricultural Smallholders: http://www.ucar.gob.ar/index.php/proinder), in the formulation of four social promotion projects. Therefore, the surveys did not originally come from a research programme. Each of these four projects took place in one of the four indigenous communities of Varas, Palca de Aparzo, Cianzo (in the province of Jujuy) and Volcán Higueras (in the province of Salta), summing up a global universe of 75 Domestic Groups (DG, from now on). No DG received funding twice; therefore, each beneficiary unit corresponds to one different DG. These surveys focused on three questions: a) the number and age of the members of the DG, b) the number and species of livestock the DG managed, and c) the purpose for which the funds received as a subsidy would be used, and the reasons why the DG believed that such a choice would improve its quality of life.

Table 1. PROINDER Projects executed in the Zenta region - years 2009/2010

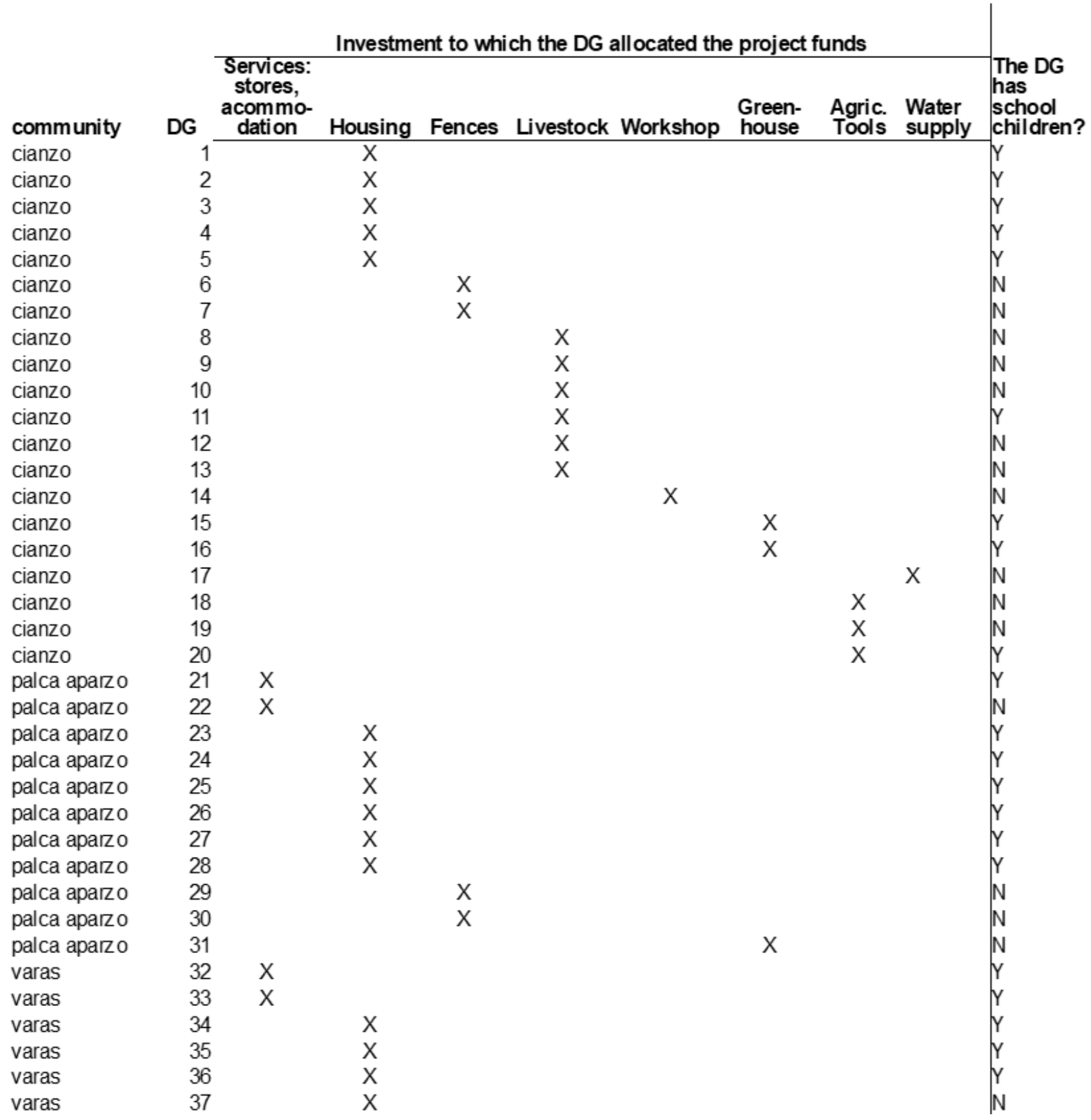


Table 1 (continued). PROINDER Projects executed in the Zenta region - years 2009/2010

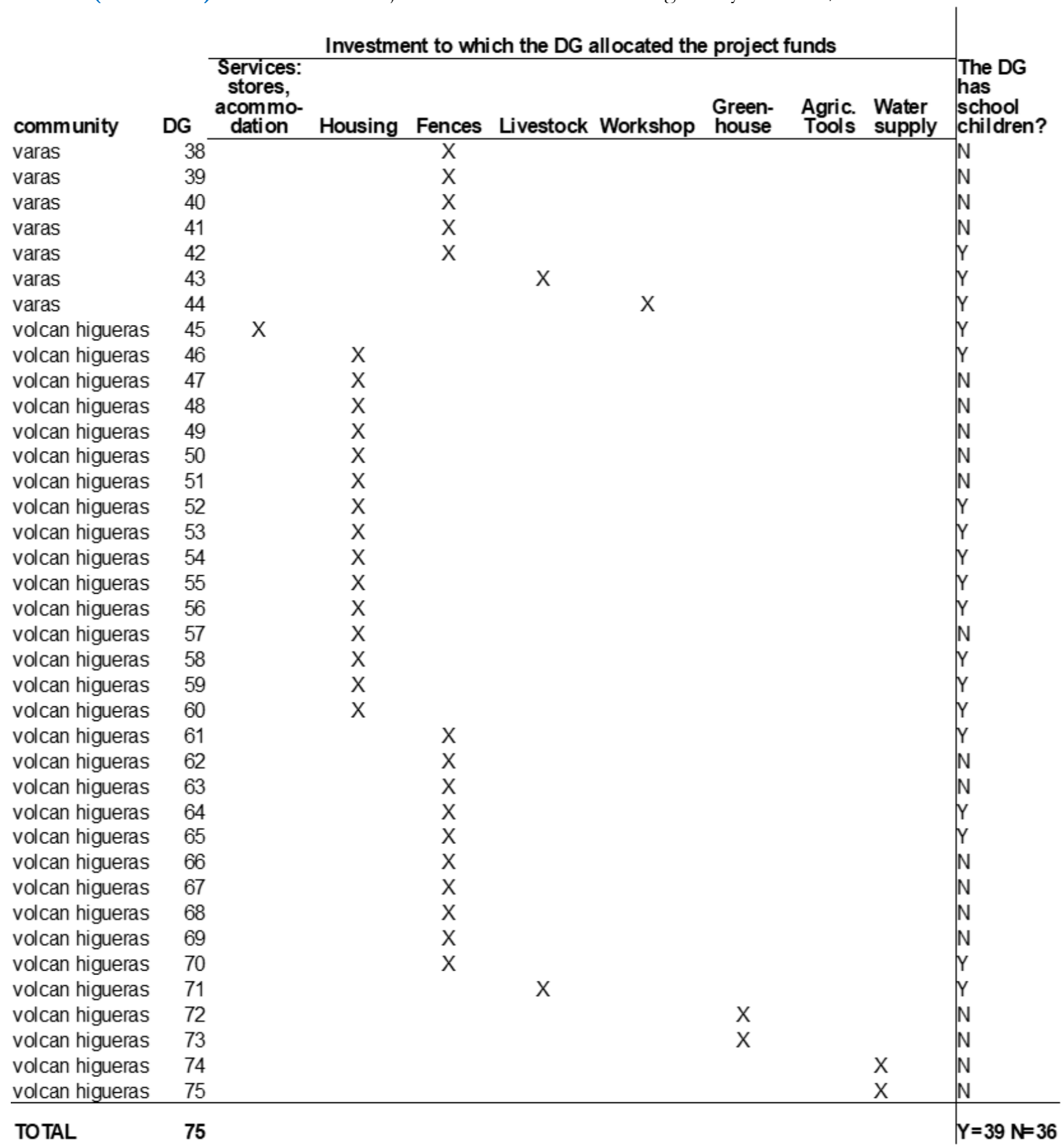

The original information obtained by the surveys was poor and incomplete for a variety of reasons, including the intelligibility of the information-gathering device for an unfamiliar population; the mistrust of older adults regarding questions about their possessions, evoking times when they had to pay leases for their land; or the mismatch between the native and the institutional meaning of certain terms - casa, hogar, vivienda, familia, ganado, propiedad -, whose local semantic complexity will be analyzed precisely in this paper. If this initial survey can be used in this opportunity, it is in a simplified manner, taking only two aspects of the responses: the presence or absence of school-age children, and the purpose for which the funds received by each DG were assigned. The table with this information (sorted by each of the four communities, but not disaggregated by name, in order to respect intrazability) is added as an annex table.

The information that is analyzed here is the result of an exercise of what Bourdieu has named 'participant objectivation' (Bourdieu, 2003), over experiences in which I have worked as a rural extensionist. For him, the objectivity of social research is not achieved by the rigor with which a certain statistical methodology is deployed in a social field - since the underlying social inequality can easily become symbolic violence (Bourdieu, 1999: 528529) -, but by means of the process of objectivation, as an exercise of epistemological vigilance over the 
researcher's own preconceptions. It is within this framework that I have built the article, not so much because I have deliberately chosen it, but above all because the limitations of statistical methods have manifested themselves recurrently throughout the social experience being analyzed.

\section{FAMILY FARMING LIVELIHOODS IN THE STUDY AREA}

Each DG carries out a multiplicity of economic activities, both agricultural and non-agricultural. These activities vary from one DG to another, but respond to a common model, which includes the following activities:

- the production of crops on small irrigated and non-irrigated agricultural units, for self-consumption as well as for sales or barter in local fairs of the cities of Humahuaca and Iruya (especially potatoes, broad beans, fodder wheat and alfalfa, and in some areas, also corn); occasionaly they can also sell some crops (peas; broad beans; gladiolus flowers) to small vegetable transport venturers who resell in the province's large grocery markets.

- the raising of large flocks of sheep (from around 60 to over 200) owned by different members of extended families, but herded by only a few family members (mainly women or children), using a system of seasonal transhumance according to yearly availability of natural pastures.

- the rearing of small quantities of cattle (from 15 to 30 or 40) in the eastern slopes, which roam freely between the temperate medium slopes during the rainfall season, and the humid lowlands in the dry winter. Cattle are visited and monitored monthly by their owners, and gathered annually to be moved from one environment to another.

- small but very important monetary incomes perceived by at least one of family members, whether from disability pensions, mine or sugar mill retirements, or children-related universal allowances.

- and finally, seasonal or yearly wage labor, which has become more and more complicated to achieve due to the economic deregulation imposed in recent decades by the neoliberal model.

As observed, communities from the Zenta mountains have very diversified income systems, combining production for self-consumption, local barter, sale of farm products in large markets, and sale of labor, as most family farming societies do all over the world (Bosc et. al. 2015). In this case, such systems take place on a very diversified environmental terrain - from warm rainforest to dry and cold higlands - creating a complex cultural mosaic of family management and movements in different territories throughout the year. However, this territorial complexity is expressed in simple and conventional Spanish terms to refer to landscape and places: valle, cerro, puna, monte, casa, puesto, estancia. In other work, I have analyzed these local semantics more extensively (Cladera, 2013). Here, I will only focus on one of those observations: the fact that the use of a specific term to refer to a place, also implies a certain conception of how to delimit family tenure within it, whether in a zero-dimensional or in a twodimensional sense.

On the one hand, DG in the Zenta mountains graze and cultivate by using sites irrigated by springs on the slopes or rivers at the bottom of the valleys. These sites, connected to each other by irrigation canals, are mutually delimited through stone walls (pircas) and fences. These plots are called rastrojos when used for cultivating, and potreros for grazing. The sum of all the rastrojos and potreros that follow one another forms a paraje. Each paraje has its own local name, but the individual plots do not.

Traditionally, the choice of the place for the erection of the family homestead was related to the largest or best irrigated rastrojo that the family had. To avoid dampening the foundations, the casas (houses) were built on top of the irrigation canals, so water had to be carried daily from the canal to the casa. One semanticly important aspect is a double meaning that the word casa has in the region, an aspect already analyzed by Tomasi (2014). Indeed, casa is the generic denomination of a set of contiguous rooms erected by successive family generations, but it is also used for each constructive unit (or room) that comprises the set; each belonging to a different member of the extended family.

According to this, the building of the casa of a young family member is one of the two situations in which the traditional system of reciprocal exchange of work, called minga or mingueada is still in force in the region (the other activity consists in the sowing of potatoes). The customary norm of the region indicates a preference for virilocality (the phrase synthesizing this norm is "the man takes the woman to his homeland"). Although exceptions to the rule are much more frequent than effective enforcement, this cultural principle establishes a procedure by which it is expected that when a child reaches the age of majority or when he gets engaged, his relatives and neighbours will help him to build a new casa, which, as we have seen, will at the same time increase the size of the family's casa.

On the other hand, DG also graze and cultivate by using another kind of landscapes: mountain slopes without irrigation. In this case, sites consist of small seasonal residences with a room and a cooking place adjacent to one or two pens, for the overnight keeping of sheep. Some of these pens - the ones with several years of use, therefore sufficiently fertilized - are used for high altitude dry farming crops that complement those obtained from the generally more temperate rastrojos. Each site formed by these housings and pens is referred to as a puesto. The surrounding periphery, where sheep and goats spend the day grazing, is called an estancia. In many different ethnographic situations I've confirmed that estancias are almost never delimited from other grazing areas. Whenever 


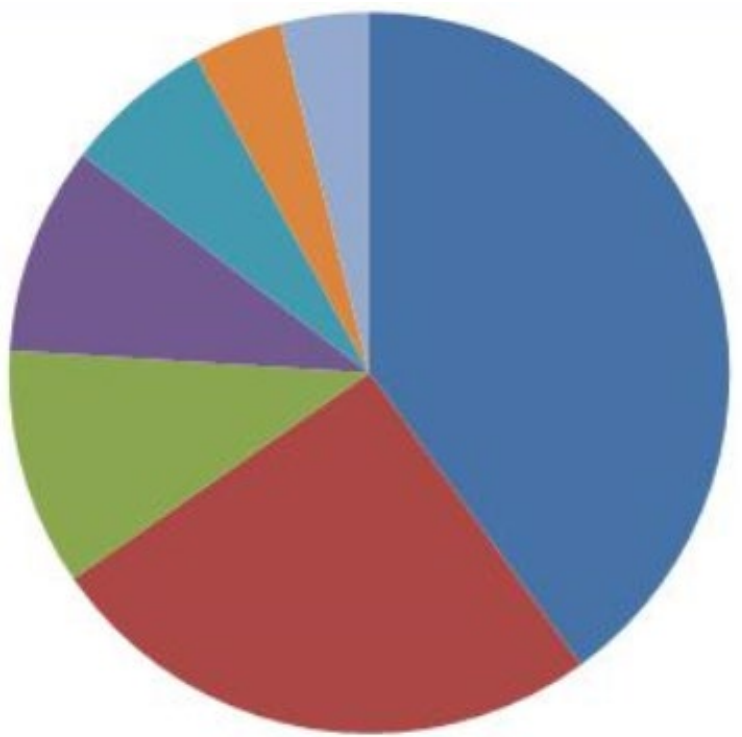

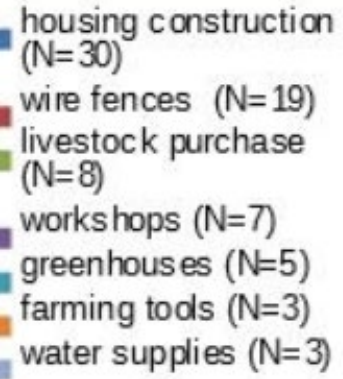

Figure 1. Allocation of funds received by PROINDER projects in the four communities analyzed

I asked where the estancia ended, the answers I received were dubious, and no specific delimiting landmark would be mentioned. Moreover, whenever I asked for the name of the estancia, the answer would always refer to the puesto, for it is the puesto that is named. That nomination is thus expanded to the surrounding estancia, not the other way round. If a new family settles somewhere, it is from that moment that the new place enters the collective mental map with a name of its own. Thus, whenever I asked a shepherd located in a specific puesto to explain to me which places would follow in a certain direction, a long list of site names would take place: every named site, every mentioned "lugar", would be invariably associated in its very verbalization, with a shepherd family, in phrases such as: "después de aqui viene Piedra Negra, que es puesto de Juan Pérez; luego viene Campo Largo que es puesto de José García". Literally: "after here comes Piedra Negra, which is Juan Pérez's puesto; then comes Campo Largo, which is José García's puesto". There's no particular named place that does not have a corresponding shepherd's name, otherwise it would simply not be mentioned, except for certain geographical features which acquire an agency comparable to that of shepherds: lagunas (lagoons), abras (mountain passes), and cumbres (peaks) (Cladera, 2013).

Thus, two different types of tenure are expressed in the Zenta Mountains through two different terms to identify the places managed by families. On the one hand, irrigated places are called rastrojos and potreros, they are clearly delimitable in space, they are chosen for the building of casas, and lack specific proper names except for the irrigated paraje within which they are situated. They therefore constitute plots appropriated by means of a twodimensional conception of tenure. On the other hand, grazing and dry-farming places situated in the mountain slopes are called puestos, they are explicitly named, and cannot be delimited since it is the very puesto as a point in space that radiates territoriality towards the surrounding environment, the estancia: constituting a zero-dimensional conception of tenure.

Each DG has at least one rastrojo and at least one puesto, but the most frequent situation is that a family has three or four of each. Both landscapes are occupied at different times of the year by different members of the family, depending on a multiplicity of factors, among which are dates for agricultural tasks, and the availability of pastures for livestock.

\section{SPACE-TIME ARTICULATIONS BETWEEN SCHOOLING AND THE TRANSHUMANCE LIVESTOCK CYCLE}

Figure 1 shows the aim for which the 75 family project funds were requested and applied. We have decided not to breakdown by community, but to present only the overall results, which constitutes an appropriate disaggregation of the information given the objectives of the analysis:

A first glance to this graph shows that two ends comprise more than $65 \%$ of the family funds requests. For $40 \%$ of families, the main concern to be solved was to improve or build one's own home. The second item selected (some 25\%) was the purchase of inputs (smooth and barbed wire, posts, turnstiles, etc.) for the installation of perimeter wire fences. As we can presume, both items manifest intentional transformations of former domestic territorial dynamics, which must be analyzed. One of the arguments most frequently used to explain the choice of a certain item was related to the school. Because of this, I decided to test the correlation between the choice of an item, and the presence or absence of school children within each household unit. The analyzed social universe 
allows such an approach, as half of the DGs - 39 - had school-age children at the moment of the surveys, and the other half - 36 - did not.

When we look at the cases of domestic groups that opted for housing funds, $73.3 \%$ had school children. On the contrary, in the case of domestic groups that chose to fence their lands, only $26.6 \%$ had children in school. We could simplify the data by saying that, in general terms, DG without schooled children prefer to close their productive places with fences, and families with schooled children opt for improving or building houses.

The elementary school has been the first State reference located directly in rural communities, as a consequence of Argentina's early efforts to disseminate secular schooling as the main tool for separating Church and State, and for consolidating Spanish as the unique and uniform national language to the detriment of local native or immigrant languages, such as, in our case of study, Quechua. The eldest school of the region was founded in 1910 in Palca de Aparzo; the school of Cianzo was founded around 1930, and the schools of Varas and Volcán Higueras were erected in the early 1970s. In fact, today one of the aspects of the community's collective identity in this region is the elementary school, along with the Catholic chapel, the cemetery, and the community corral for the annual donkey rodeos.

As in many traditional rural livelihoods, DG must solve the problem of the incompatibility between young students' schooling fulfillment requirements on the one hand, and the material conditions of domestic reproduction (Meillassoux, 1999), on the other. Schooling requires a rearrangement of the available family resources, since daytime livestock herding is a task usually assigned to children in many pastoral societies (FAO, 2013). Second, schools also demand a rearrangement of family mobility practices, since children obviously have to remain in the same place where classes are given.

During the first years of fieldwork, I had the opportunity to witness some transhumant mobility practices undergoing profound modifications and that during the successive years ceased completely, but that are referred to as ancestral practices - those that preceding generations used to do ("como hacian los abuelos"). Those traditional practices of mobility involved the transfer of the entire domestic unit from one puesto to another, including men, women, children, cattle and sheep, to make sure that the availability of fodder resources was never critical. Therefore, traditionally, people would live the rainy half of the year in their temperate midslope puestos, and the dry half of the year in the humid eastern lowlands, cultivating two different plots simultaneously, one at each place. Both plots needed to be checked as they grew, therefore a periodic displacement of some family members from one puesto to the other was necessary (Cladera, 2010).

Such a territorial model manifests as an evident difficulty for schooling activities. Many different strategies have been employed to solve (or at least decrease) this tension between domestic mobility and the school cycle.

The first solution has consisted in the transfer of the school itself along with the families. I have not witnessed the practice personally, but a strategy like this apparently was used in another large estate adjacent to the study area - Finca San Andrés, in the province of Salta - until the mid-1980s, according to testimonies recovered by other scholars (Brown et.al., 2007; Luñis Zavaleta, 2004). These testimonies manifest that the teachers moved with the shepherd families to the humid lowlands between May and June, and that they would return back to the temperate midslopes in October or November (see Luñis Zavaleta, 2004: 78).

A strategy of this type was very fragile and would eventually become intolerable for State administrative criteria, or for the vocational continuity of teachers. With the "foundation" of permanent villages in the lowlands (Luñis Zavaleta, 2004), these practices of "school transhumance" fell into disuse.

Another option is not to move the school, but the student's enrollment, from one school to another halfway through the school year. This practice is known locally as "pedir el pase" ("requesting a pass"). In my first year entering the territory, there was still one family in Volcán Higueras that had implemented this type of strategy until the previous year. But, the reasons for abandoning the strategy were many: because of the administrative burden on parents to ask for a pass each year; because of the drastic enrollment reduction at mid-year in one of the schools and the consequent difficulty in justifying its expenses; because of the inevitable decline in children's educational quality; and so on. When I met him, the father of this family unit was applying for a temporary job at the Volcán Higueras School, so that he and his family could stay in this community throughout the year.

So far we have seen two strategies in which the domestic reproduction conditions were dominant (Godelier, 1976) over those demanded by State institutions. That is to say, in these situations there was a predominance of livestock practices over schooling, even forcing the latter to adapt as much as possible to the former. This was historically unstable, for it was intolerable for the State administration. Over time, various indirect operations have been acting to reverse the priority relationship: the school is gaining prominence, forcing livestock practices to subordinate themselves to it and families to see how they can solve the subsistence problem that ensues.

A third possible solution is that the school has hosting conditions to keep its students during the whole week; that is, a boarding school. In Spanish, these institutiones are known as "escuelas-albergue" (lit. "shelter-schools"). Two of the four local schools in the study case are boarding schools, and several families with one or two school children use these facilities. However, if a family has only one or two children at school, it is almost always because 

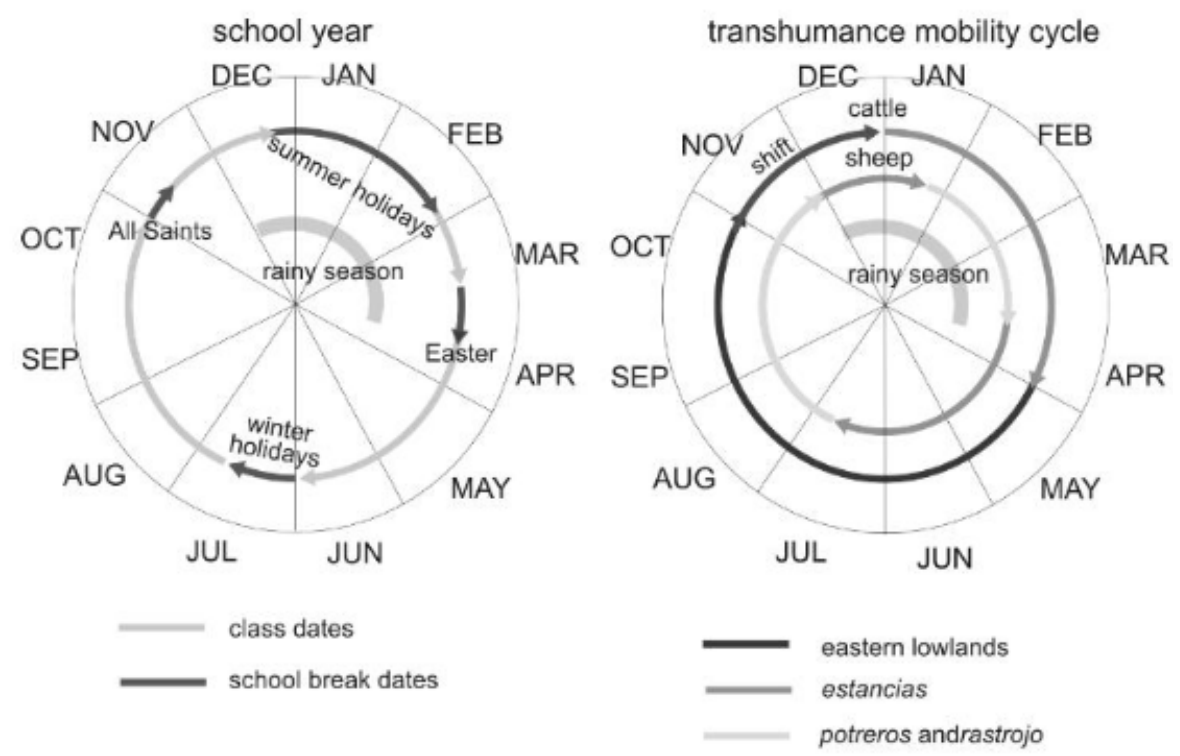

Figure 2. Comparative annual calendars of the school year (left) and the current transhumance mobility cycle (right)

it constitutes a family unit in its replacement stage (Fortes, 1969). In the Andean systems, the youngest son or daughter must take care of the parents in their old age, in exchange for which he or she will inherit the grazing territories when the parents die (Mayer \& Bolton, 1980). In the Zenta region, this task is exercised mainly by a grandson or granddaughter who lives with his/her grandparents. There's a specific native word used in the Zenta mountains to name this child: el pichule if he is a boy, or la picbule if she is a girl.

But when a DG has a high number of children in school (as is the case with families in their expansion stage), the pressure for parents to remain close to their children is accentuated; therefore, other solutions must be sought. The most definitive solution is to reduce livestock transfers as much as possible. In the case of sheep grazing, a strategy may be to carry out short distance transfers between nearby puestos at different heights over the same mountain slope. But cattle will have to remain alone and only sporadically visited in the eastern lowlands during the winter months. In any case, schooling becomes a dominant activity over livestock, and, consequently, the quantity of livestock and the quality of the products obtained from it are diminished. Therefore, this creates an unsolved subsistence problem. In order to reduce it as much as possible, DGs seek to integrate school and livestock activities into a uniform task schedule, as shown in Figure 2.

The graph on the left shows the school year and the school breaks. The graph on the right shows today's annual livestock movements cycle. As observed, many date coincidences are identifiable. These coincidences are not casual.

We observe that the first days of the summer holidays can be used by teenage girls or by elementary school children to help their mothers to transfer sheep from potreros to estancias for a short period during which lambs are born and people can milk sheep and make cheese and other products. Almost at the same time, teenage boys help their fathers to move cattle from eastern lowlands and slopes to estancias, where they will remain grazing during the whole rainy season. Another alternative is to transfer cattle during the short schoolbreak of All Saints Fest ( $1^{\text {st }}$ and $2^{\text {nd }}$ November), which is usually a provincial holiday. After the milking period, DGs return with their sheep to their potreros, towards the end of January, still coinciding with the holidays.

A second sheep transfer requires returning them back from potreros to estancias, to take advantage of the last remaining grass, and simultaneously transfer the cattle from estancias back to the lowlands. These transfers happen during Easter's school break.

Finally, winter holidays are used to transfer sheep again from estancias (where there is no available pasture left) to rastrojos, where they will spend the coldest and driest period feeding on crop stubbles and alfalfa.

As it can be seen, the transhumance cycle that is performed today is not determined exclusively by sheep and cattle fodder needs, but it rather constitutes a creative strategy to coordinate as much as possible schoolbreaks with livestock transfers. However, the more the family is conditioned by the school year, the less time they can devote to livestock, making their livelihoods more vulnerable. The only alternative that ensures the continuity of the family unit in its territory is the one offered by the school itself. 


\section{ON HOUSING PROJECTS: SCHOOL JOBS AND “YOUNG” DOMESTIC GROUPS}

In some of the family projects, the choice to invest in housing was due to the necessity to keep children closer to the school so that they could go and return during the day, something they cannot do if they have to return to their family's traditional puestos, sometimes several hours away from school.

But in most situations, the choice had to do not only with the former reason, but also with the expectation of some family members to apply for a job at the school itself. Indeed, all rural schools in these communities absorb a set of neighbours as non-teaching staff through precarious temporary contracts: including categories such as "caretaker", "doorman", “cook", "cleaning staff", "greenhouse manager", and so on. All these activities are poorly remunerated, but nevertheless provide some family members with a small monthly income that helps to reduce the extreme vulnerability of sustaining the reproduction of the DG exclusively through the agricultural activities. If parents don't get a school job, their only options are seasonal jobs in different agricultural poles of the country, especially Mendoza, Patagonia, and the tobacco harvest in tropical Jujuy. The possibility of having a monthly remuneration in the same locality of origin, as the school offers, is of value even when it means less income than that of seasonal migration, since there are no mobility or living expenses.

Indirectly, the school also generates other economic mobilizations of very small scale, but of significant impact in local terms. For example: the school buys several supplies locally, especially food for the student canteen: potatoes, maize, beans, vegetables, eggs, fruit, meat, poultry. This is highly valued by neighbors, who see local schools as a daily return opportunity for the sale of small quantities of agricultural products. Some State policies have been directly targeted at facilitating this supplying role, such as the so called "Monotributo Social para la Agricultura Familiar" (lit.: Social Monotax for Family Farming), which was in force between 2013 and 2018. ${ }^{1}$

In addition, rural schools mobilize another resource: teacher salaries, since teachers have to stay in the locality during the week and must consume food every day, wash clothes, and have a place to stay. These services are often provided by families in the surrounding areas, including in some cases hosting: a valuable, safe and profitable monthly income.

A third type of locally valued service offered by schools is vehicular transportation. Teachers must be transferred from the departmental capital city - Iruya or Humahuaca, in our case - every Monday at the beginning of classes, and back every Friday. This service, which is the responsibility of the provincial school board, provides a highly predictable option for the transfer of information, people and goods in emergency situations. It also incorporates an institutional actor into the demands of road maintenance, facilitating small private ventures to offer daily transport services much easier and faster than traditional transport by means of donkeys and mules.

The gravitational character of the school, not only as a conditioner but also as an economic alternative for local DGs, especially for those who are in the expansion stage, has been expressed in the preference to build houses closer to the school with the project funds, before any other investment. Not only to facilitate the access of children to school, but essentially to increase the family participation in the small markets for goods and services that are woven around and by the school. This participation entails a partial interruption of the wide-range territorial practices that used to be carried out in the past.

\section{ON FENCE PROJECTS: OPEN FIELDS AND “MATURE” DOMESTIC GROUPS}

Fences are chosen as the priority investment by DG without responsibility for school children, that is to say, who are going through the fission stage (Fortes 1969): either because their own children have grown up and have left the locality or formed their own DGs, or because they never lived in the locality, in the case of families that "returned" in their maturity to their homelands with a pension or a retirement that makes it easier for them to fully dedicate themselves to rural tasks (as has been identified in other Andean regions: Cortes 2004; Vassas-Toral 2016). What is certain is that families that intensify their agricultural productive activity coincide with those on which the current demographic reproduction of the communities does not depend.

Some DGs need wire fences to replace or complete sections of the traditional stone and mud pircas, since the traditional pirca techniques require a lot of work, and the installation of wire fences is much faster and requires less energy. In these cases, fences are used to close and separate already irrigated rastrojos. The most frequent argument for fence installation has to do with donkey damage. Donkeys are not strictly bred but handled almost like wild livestock, grazing freely on the mountain slopes for most of the year, until the annual rodeo during Lent. Consequently, when pastures become scarce on the mountain slopes at the end of winter, donkeys descend

\footnotetext{
${ }^{1}$ See: https://www.agroindustria.gob.ar/sitio/areas/d_registros_y_monotributo_agropecuario/msa/.
} 
attracted by corn, barley or wheat stubbles, alfalfa reserves and other available fodder. In this sense, wire fences reinforce traditional agricultural production in the irrigated areas.

However, some other DGs utilize fences to create new enclosures. In the non-irrigated slopes, investing in wire fences has sometimes been made to increase the agricultural extension provided by the pens; and sometimes for pasture reserves that serve as a dietary complement for livestock towards the end of the rainy season. Although seasonal movements of livestock from one estancia to another cannot be replaced, the expectation of shepherds is that by adequately reducing the size of their flocks, the installation of perimeter fences around some puestos will at least save them the most distant and fatiguing livestock transfers.

So, while in the case of irrigated areas, fences help to reinforce traditional territorial practices, in the case of non-irrigated mountain slopes, fences are installed precisely to configure the relationship of people and places in a different way from the traditional one. The effort to establish large hillside surface enclosures tends to reduce the time and energy used in transhumance practices. In doing so, the spatial terms used for the designation of sites are also forced to vary. What had once been called a puesto with its surrounding estancia, becomes - from the moment of its enclosure and two-dimensional reconversion - a potrero.

\section{DISCUSSION AND CONCLUSIONS: CASAS ARE BEING LEFT AS PUESTOS AND ESTANCIAS ARE BECOMING POTREROS}

The intention of this article has been to analyze the territorial transformations that are occurring among the pastoral Andean communities as an active process in which these societies are readapting, through creative manipulations, both their own traditional ontologies, and the School as a modernization device promoted by the State. I have tried to highlight the ways in which pastoral domestic units promote transformations in their daily territorial dynamics, in order to achieve what they visualize as concrete improvements in their quality of life. These transformations do not necessarily face in an antagonistic way the modernization devices imposed by the State such as Elementary Schools, but on the contrary, they adopt these institutions, and in doing so, they endow them with innovative functions and purposes that were not the ones from their original and explicit program. In the case of schools, we have observed how the manifest pedagogical function of these institutions is complemented by another role: as drivers of local economic circuits. This social role becomes so important that DG facing an expansion stage (Fortes 1969) promote various strategies to adapt the other spheres of their daily economy to the possibilities offered by schools. Simultaneously, the families in a fission stage are fostering a productive intensification of their lands, in aim of profiting from the commercial circuits that, directly and indirectly, are woven around the schools.

Both dynamics promote opposite transformations in the daily territorialities, which are manifested in local terms. To express the territorial dynamics of younger DGs, I heard a local sentence: "las casas van quedando de puestos" ("casas are being left as puestos"). Indeed, ancient extended family casas sited in rastrojos devoid of schools, are today increasingly becoming sites for seasonal livestock grazing, that is, open field puestos. Meanwhile, new casas are being built around or near schools, in semi-urban hamlets where it is easier to manage collective resources, such as domestic water supplies, electrical lines or access roads, but above all, where it becomes easier to access economic activities linked to the services offered or demanded by the school for its operation.

On the other hand, elder DGs, under other economic conditions and family responsibilities, are more willing to intensify the traditional productive systems, by means of territorial modifications. Although in many cases the fences reinforce pre-existing enclosures, there are cases in which a transformation in the condition of territoriality is evident: the enclosure of estancias, which consequently cease to be so, to become potreros.

In both cases, modification of the terms used to designate the sites entails a parallel modification of the tenure demarcation criteria associated with them. What were once places of daily circulation in which a two-dimensional type of tenure was performed - casas located in rastrojos - are becoming sites of unrestricted circulation, demarcated zero-dimensionally - puestos. At the same time, what once were open circulation, zero-dimensionally conceived fields - estancias - are now being circumscribed to places of particular access removed from the commons - potreros.

These two opposing tenure dynamics nevertheless reveal an underlying territorial intentionality that is shared by both social categories: the intention to reduce the effort in time and energy demanded by the most exhausting forms of spatial displacement, in favor of more circumscribed livestock management dynamics, with a smaller participation of the most remote puestos. It is therefore undeniable that pastoral societies in the Andes are going through profound processes of territorial transformation, but to express these dynamics either in terms of social crisis or erosion, or of social prevalence, constitute analytical simplifications insufficient to explain a vital, complex and creative cultural reality. 


\section{REFERENCES}

Abeledo, S. (2013). Pastores de los Andes Meridionales. Sistemas tradicionales de intercambio y sus transformaciones en Santa Rosa de los Pastos Grandes (Los Andes, Salta) (Doctoral Thesis). Buenos Aires: FFyL - UBA.

Abeledo, S. (2014). Territorio, caminos y prácticas culturales de los viajes de intercambio del último siglo (departamento de Los Andes, provincia de Salta. In J. Tomasi and A. Benedetti (eds.), Espacialidades altoandinas. Nuevos aportes desde la Argentina. Miradas hacia lo local, lo comunitario y lo doméstico. Buenos Aires: Editorial FFyL UBA.

Abeledo, S. (2018). La minería y su incidencia en el modo de vida pastoril de Santa Rosa de los Pastos Grandes. In H. R. Grau, M. J. Babot, A. E. Izquierdo and A. Grau (eds), La Puna argentina: naturaleza y cultura (pp. 423-425). San Miguel del Tucumán: Fundación Miguel Lillo.

Assadourian, C. S. (1982). El sistema de la economía colonial. Mercado interno, regiones y espacio económico. Lima: Instituto de Estudios Peruanos.

Barth, F. (1976). Los grupos étnicos y sus fronteras. México D.F.: Fondo de Cultura Económica.

Benedetti, A. and Tomasi, J. (2014). Introducción, in Espacialidades altoandinas. Nuevos aportes desde la Argentina (pp.1127). Buenos Aires: Editorial de FFyL - UBA.

Bosc, P.-M., Sourisseau J.-M., Bonnal P., Gasselin P., Valette E. and Bélières J.-F. (2015). Diversité des Agricultures Familiales de par le Monde. Exister, se transformer, devenir. Versailles: Éditions Quae. https://doi.org/10.35690/9782-7592-2268-1

Bourdieu, P. (1999). Comprender, in La miseria del mundo. Buenos Aires: Fondo de Cultura Económica.

Bourdieu, P. (2003). Participant objectivation. Journal of Royal Antbropolgy Institute, (9), 281-294. https:// doi.org/10.1111/1467-9655.00150

Brown, A., García Moritán, M., Ventura, B., Hilgert, N. and Malizia, L. (2007). Finca San Andrés. Un espacio de cambios ambientales y sociales en el Alto Bermejo. S. Miguel del Tucumán: Fundación Proyungas and Ediciones del Subtrópico.

Cladera, J. (2010). Continuidad y Cambio en las prácticas trashumantes. El caso de los ganaderos del circuito Iscuya-Astilleros, Comunidad Kolla Finca Santiago, provincia de Salta. Kula, Antropólogos del Atlántico Sur, (3), 55-65.

Cladera, J. (2013). Pessoas que cruzam territórios, e territórios que são pessoas. As experiéncias do direito espacial nos Andes desde um caso no noroeste argentino. Ilha, 15(1), 149-178. https://doi.org/10.5007/21758034.2013v15n1-2p149

Cortes, G. (2004). Partirpara quedarse. Supervivencia y cambio en las sociedades campesinas andinas de Bolivia. La Paz: IFEA - IRD - Plural. https:// doi.org/10.4000/books.ifea.4368

Cowan Ros, C. (2007). De la producción del capital social a la lucha simbólica en el contexto territorial, in M. Manzanal, B. Nussbaumer and M. Arzeno (org.) Territorios en construcción (pp. 225-254). Buenos Aires: CICUS.

Cowan Ros, C. (2013). Laberintos de emancipación: reciprocidad y conflicto en las relaciones de mediación entre agentes de promoción social y dirigentes campesinos. Revista de Antropología Social, (22), 287-312. https://doi.org/10.5209/rev_RASO.2013.v22.43192

Echenique, M., Chávez M. F., Vittar M. E. and Longoni A. (2015). Análisis de la dinámica del stock ganadero de la Puna de Jujuy, su importancia productiva actual, problemáticas y posibles techos productivos. Buenos Aires: Ediciones INTA.

FAO. (2013). Children's work in the livestock sector: Herding and beyond. Rome: FAO. Available at: http://www.fao.org/3/i3098e/i3098e.pdf

Fernandes, B. Mançano. (2005). Movimentos socioterritoriais e movimentos socioespaciais: Contribuição teórica para uma leitura geográfica dos movimentos sociais. OSAL - Observatorio Social de América Latina, (16), 273-283.

Fortes, M. ([1958] 1969). Introduction. In J. Goody (ed.) The Development Cycle in Domestic Groups (pp. 1-14). London: Cambridge University Press.

Göbel, B. (2002a). La arquitectura del pastoreo: uso del espacio y sistema de asentamientos en la Puna de Atacama (Susques). Estudios Atacameños (En línea), (23), 53-76. https://doi.org/10.4067/S0718-10432002002300005

Göbel, B. (2002b). Identidades sociales y medio ambiente: la multiplicidad de los significados del espacio en la puna de Atacama. Cuadernos del Instituto Nacional de Antropología y Pensamiento Latinoamericano, (19), 267-296.

Godelier, M. (1976). Antropología y Economía. Barcelona: Editorial Anagrama.

Guber, R. (2004). El salvaje metropolitano. Reconstrucción del conocimiento social en el trabajo de campo. Buenos Aires: Paidós ( $1^{\circ}$ ed.).

Hocsman, L. D. (2011). Estrategias territoriales, recampesinización y etnicidad en los andes de argentina. Buenos Aires \& México: UNAM / CLACSO.

Ingold, T. (1987). Territoriality and tenure: the appropriation of space in hunting and gathering societies. In The appropriation of nature. Essays on buman ecology and social relations (pp. 130-164). Iowa: University of Iowa Press. 
Jacobsen, S. E. (2011). The situation for quinoa and its production in Southern Bolivia: from economic success to environmental disaster. Journal of Agronomy and Crop Science, 197(5), 390 -399. https://doi.org/10.1111/j.1439037X.2011.00475.X

Kerssen, T. M. (2015). Food sovereignty and the quinoa boom: challenges to sustainable re-peasantisation in the southern Altiplano of Bolivia. Third World Quarterly, 36(3), 489-507. https://doi.org/10.1080/01436597.2015.1002992

Lencina, R., Peralta, E. and Sosa Gómez, J. (2018). La actividad minera en la Puna argentina. Caracterización sociohistórica, presente y perspectivas. In H. R. Grau, M. J. Babot, A. E. Izquierdo and A. Grau (eds), La Puna argentina: naturaleza y cultura (pp. 422-426). San Miguel del Tucumán: Fundación Miguel Lillo.

Longhi, F. and Krapovickas J. (2018). Población y pobreza en la Puna argentina en los inicios del siglo XXI. In H. R. Grau, M. J. Babot, A. E. Izquierdo and A. Grau (eds), La Puna argentina: naturaleza y cultura (pp. 364-379). San Miguel del Tucumán: Fundación Miguel Lillo.

Luñis Zavaleta, F. (2004). Memorias de un conflicto. Finca San Andrés. In E. Belli, R. Slavutsky and H. H. Trinchero (eds.), La Cuenca del Bermejo. Una formación social de fronteras (pp. 67-87). Buenos Aires: Editorial Reunir.

Malinowski, B. (1923). The Problem of Meaning in Primitive Languages. In C. K. Ogden and I. A. Richards (eds.), The Meaning of Meaning (pp. 296-336). London: K. Paul, Trend, Trubner.

Mayer, E. and Bolton, R. (eds.). (1980). Parentesco y matrimonio en los Andes. Lima: PUCP.

Medinaceli, X. (2005). Los pastores andinos: una propuesta de lectura de su historia. Ensayo bibliográfico de etnografía e historia. Bulletin de l'Institut français d'etudes andines, 34(3), 463-474. https://doi.org/10.4000/bifea.5000

Meillassoux, C. ([1975] 1999). Mujeres, graneros y capitales. México D. F.: Siglo XXI (12ed.).

Mörner, M. (1975). La hacienda hispanoamericana: Examen de las investigaciones y debates recientes, in E. Florescano. (Ed.), Haciendas, latifundios y plantaciones en América Latina. México D. F.: Siglo XXI.

Parker-Gibson, N. (2015). Quinoa: Catalyst or Catastrophe? Journal of Agricultural \& Food Information, 16(2), 113122. https://doi.org/10.1080/10496505.2015.1016816

Paz, R. (2006). ¿Desaparición o permanencia de los campesinos ocupantes en el noroeste argentino? Evolución y crecimiento en la última década. Canadian Journal of Latin Amercian and Caribbean Studies, 31(61), 169-197. https://doi.org/10.1080/08263663.2006.10816894

Paz, R., Sossa Valdéz, F., Lamas, H., Echazú, F. and Califano, L. (2012). Diferenciación social y procesos de mercantilización en los campesinos de la puna jujeña (Argentina). Estudios del Trabajo, 43/44, 49-80.

Puente, F. and Argento, M. (2015). Conflictos territoriales y construcción identitaria en los salares del noroeste argentine. In B. Fornillo (ed.), Geopolitica del Litio: Industria, Ciencia y Energía en Argentina (pp. 123-166). Buenos Aires: El Colectivo.

Quiroga Mendiola, M. (2013). Llueve sobre mojado... Trashumancia conceptual frente al pastoralismo altoandino. In M. Manzanal M. and M. Ponce M (eds.), La desigualdad ¿ del desarrollo? Controversias y disyuntivas del desarrollo rural en el norte argentino (pp. 253-272). Buenos Aires: CICCUS.

Quiroga Mendiola, M. and Ramisch, G. (2013). ¿Pastores o asalariados? Tierra y trabajo en las altas montañas del noroeste de Argentina. In D. Ramilo and G. Prividera (eds.), La Agricultura Familiar en la Argentina. Diferentes abordajes para su estudio (pp. 133-156). Buenos Aires: Ediciones INTA.

Rutledge, I. (1987). Cambio agrario e integración: el desarrollo del capitalismo en Jujuy, 1550-1960. Tilcara: ECIRA-CICSO.

Schiaffini, H. (2014). Litio, llamas y sal en la Puna argentina Pueblos originarios y expropiación en torno al control territorial de Salinas Grandes. Revista de la carrera de Sociologia entramados y perspectivas, 3(3), n/d.

Scott, J. (1987). Weapons of the Weak: Everyday Forms of Peasant Resistance. New Haven \& London: Yale University Press.

Scott, J. (1998). Seeing like a State. How certain schemes to improve the human condition have failed. New Haven \& London: Yale University Press.

Tomasi, J. (2011). La casa como una construcción múltiple y colectiva. Aproximaciones al espacio doméstico en Susques y Rinconada. In J. Tomasi and C. Rivet (eds.), Puna y arquitectura. Las formas locales de la construcción (pp. 41-51). Buenos Aires: CEDODAL.

Tomasi, J. (2014). De los pastoreos a la casa. Espacialidades y arquitecturas domésticas entre los pastores altoandinos (Susques, provincia de Jujuy), in J. Tomasi and A. Benedetti (eds.), Espacialidades altoandinas. Nuevos aportes desde la Argentina. Miradas hacia lo local, lo comunitario y lo doméstico (pp. 257-299). Buenos Aires: Editorial FFyL - UBA.

Vassas Toral, A. (2016). Partir y cultivar. Ange de la quinua, movilidad y recomposiciones rurales en Bolivia. La Paz: IRD /CIDES - UMSA / Plural Editores. https://doi.org/10.4000/books.irdeditions.18216

Walsh-Dilley, M. (2016). Tensions of resilience: collective property, individual gain and the emergent conflicts of the quinoa boom. Resilience. International Policies, Practices and Discourses, 4(1), 30-43. https://doi.org/10.1080/21693293.2015.1094168 
Weinberg, M. (2004). Identidades y organización política en la comunidad Kolla de Finca Santiago. Iruya, Salta. Estudios Sociales del NOA, 7, 43-65.

Winkel, T., Cruz, P., Álvarez-Flores, R., Bertero, D., Del Castillo, C., Gasselin, P., ... Vieira-Pak, M. (2015). El presunto desastre ambiental y social de la quinua real: desarmar los clichés para reforzar la ética. T'inkazos, 18(38), 127-142. 